\title{
M ethane emissions from lambs fed kikuyu hay alone or mixtured with lotus hay
}

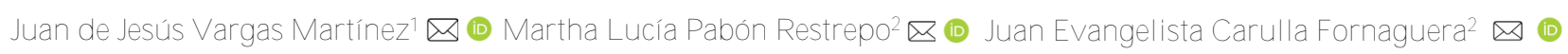

Red de Ganadería y Especies Menores. Corporación Colombiana de Investigación Agropecuaria (AGROSAVIA), Centro de Investigación Tibaitatá. Mosquera, Cundinamarca, Colombia.

\begin{abstract}
A bstract. Dietary inclusion of contain-tannin legumes may reduce enteric methane emission in ruminants. To evaluate methane emissions from sheep fed with a kikuyu grass (Cenchrus clandestinus) diet partially substituted with lotus (Lotus uliginosus), twelve growing lambs, with $23 \pm 2 \mathrm{~kg}$ average liveweight, were assigned randomly to two treatments and with three measurement periods in a switchover design. Treatments consisted of $100 \%$ kikuyu hay or $70 \%$ kikuyu hay: $30 \%$ lotus hay and with 6 lambs per treatment. Each of three periods lasted $20 \mathrm{~d}$, where the first $15 \mathrm{~d}$ were for acclimatization and the last $5 \mathrm{~d}$ for measurements. Lambs were placed in metabolic cages and fed once a day (8 AM) at $90 \%$ of their voluntary feed intake, with free access to drinking water. Feed intake, fecal production and feed digestibility were determined at each period. Methane production was measured for each treatment group of 6 lambs using the poly-tunnel technique. Legume addition reduced total methane production (27.6 vs. $23.1 \mathrm{~g}_{\text {animal-1; }} \mathrm{p}<0.01$ ), methane production per dry matter intake (DMI) (18.8 vs. $12.2 \mathrm{~g} \mathrm{~kg}^{-1} \mathrm{DMl} ; \mathrm{p}<$ 0.01 ), methane production per digestible OM (DOM) (36.1 vs. $23.4 \mathrm{~g} \mathrm{~kg}^{-1} \mathrm{DOM} ; \mathrm{p}<0.01$ ) and methane production per digestible NDF (DNDF) (43.5 vs. $34.0 \mathrm{~g} \mathrm{~kg}^{-1}$ DNDF; $\mathrm{p}<0.01$ ). In conclusion, lotus inclusion in pasture systems could be a suitable legume to reduce methane emissions in grazing systems.
\end{abstract}

Key words: Feeding systems, greenhouse gases, methanogenesis, contain-tannin legumes.

\section{Producción de metano de corderos alimentados con heno de kikuyo solo o mezclado con heno de lotus}

Resumen. La inclusión de leguminosas taníferas puede reducir las emisiones de metano entérico en rumiantes. Para evaluar la incorporación de lotus (Lotus uliginosus) a una dieta basal de kikuyu (Cenchrus clandestinus) sobre la emisión de metano en ovinos, doce corderos con peso vivo de $23 \pm 2 \mathrm{~kg}$ fueron asignados aleatoriamente a dos tratamientos en tres periodos de medición en un diseño de sobrecambio compuesto. Los tratamientos fueron $100 \%$ heno de kikuyo o $70 \%$ heno de kikuyo y $30 \%$ heno de lotus con seis corderos por tratamiento. Cada uno de los tres periodos duró de $20 \mathrm{~d}$, en donde los primeros 15 d fueron de adaptación y los últimos $5 \mathrm{~d}$ de medición. Los corderos fueron alojados en jaulas metabólicas, alimentados una vez al día (8 AM) al $90 \%$ de consumo voluntario y tuvieron agua a voluntad. El consumo de MS, la producción de heces y la digestibilidad del alimento fue determinada para cada periodo. La producción de metano fue determinada para cada grupo de 6 corderos a través de la técnica del poli-tunel. La inclusión de leguminosa redujo la emisión de metano total (51.6 vs. $43.1 \mathrm{~g}$ animal-1; $p$ $<0.01$ ), metano respecto a la materia seca consumida (MSC) (18.8 vs. $12.2 \mathrm{~g} \mathrm{~kg}^{-1} ; \mathrm{p}<0.01$ ) y metano respecto a la materia orgánica digerida (MOD) (36.1 vs. $23.4 \mathrm{~g} \mathrm{~kg}^{-1} ; \mathrm{p}<0.01$ ). En conclusión, el lotus podría ser una leguminosa adecuada para reducir las emisiones de metano en sistemas pastoriles.

Palabras claves: Sistemas de alimentación, gases efecto invernadero, metanogénesis, leguminosas taníferas.

\section{Introduction}

Methane is the main greenhause gas contributed by livestock farming and it also represents an energertic loss (Gerber et al., 2013). Therefore, strategies to reduce methane production could decrease its impact in climate change and, at the same time, increase the efficiency of energy use by ruminants (Makkar, 2016). Nutritional manipulation of the diet characteristics can modify enteric methane emissions and animal efficiency (Johnson and Johnson, 1995, Lovett et al., 2005)
Worldwide, a significant proportion of ruminants use pastures as their main source of feed. In in vivo studies, legumes with low content of condensed tannins included in pasture basal diets of grass presented contradictory results. For example, Carulla et al. (2005) suggested that methane emissions per unit of dry matter intake by sheep increased when clover was included in a basal diet of ryegrass. On the other hand, Lee et al. (2004) reported that methane production per unit of dry matter consumed by cattle

${ }^{2}$ Grupo de Investigación en N utrición A nimal. Departamento de Producción A nimal, Universidad Nacional de Colombia Bogotá, Colombia. 
decreased when the proportion of white clover in the diet increased. Similar results were reported when tanniferous legumes were included in diets of sheep and cattle (Woodward et al., 2004; Tiemann et al., 2008a).

There is little information that assesses methane emissions in tropical highland conditions. Archimède et al. (2011) reported information from trials showing lower methane production from C3 compared to C4 grasses and from tropical versus temperate legumes. The aim of this experiment was to determine the methane emissions from lambs when lotus (Lotus uliginosus) hay, a tanniferus forage legume, was added to a basal diet of kikuyu (Cenchrus clandestinus) hay.

\section{M aterials and M ethods}

All procedures were approved by the Bioethics Committee of the Facultad de Medicina Veterinaria y de Zootecnia, Universidad Nacional de Colombia, (Act 007 of 2010 with number CBE-FMVZ-026).

\section{Localization}

The experiment was carried out at the Tibaitatá Research Center, located in the municipality of Mosquera, Cundinamarca (2 560 meters above sea level, $13{ }^{\circ} \mathrm{C}$ average temperature, with fluctuations between $0{ }^{\circ} \mathrm{C}$ and $20{ }^{\circ} \mathrm{C}$ ). The average annual precipitation is $528.9 \mathrm{~mm}$ with a bimodal distribution of two rainy periods, one between A pril and May and other from September to November, and 80-85\% relative humidity (Vargas et al., 2018a).

\section{Forage Species}

Two different paddocks, one of kikuyu grass (Cenchrus clandestinus) and another of lotus (Lotus uliginosus) were harvested at 50 days of regrowth. The harvested fodder was dried, packed and stored at room temperature.

\section{Animals and experimental design}

Twelve creole growing lambs, with $23 \pm 2 \mathrm{~kg}$ of live weight and $6 \pm 2$ month of age, were housed in individual metabolic cages and randomly assigned to two groups of 6 animals each. The groups were assigned to an experimental switching design consisting of 2 (treatments) $\times 3$ (periods). The experimental treatments were $100 \%$ kikuyu hay and $70 \%$ kikuyu hay and $30 \%$ of lotus hay. Three experimental periods of $20 \mathrm{~d}$ each were carried out. During the first $7 \mathrm{~d}$ of each period, the lambs were fed ad libitum to determine voluntary intake. The next 13 $\mathrm{d}$ feed offered was restricted to $90 \%$ voluntary intake to reduce selectivity and ensure total feed consumption. Feed was allocated once a day. Each group of 6 animals placed in cages were placed in one of two tunnels $7 \mathrm{~m}$ long, $5 \mathrm{~m}$ wide and $2.6 \mathrm{~m}$ high (total volume $83.5 \mathrm{~m}^{3}$ ) to estimate methane emissions following the procedure proposed by Molina et al. (2016).

Dry matter intake, and feces and urine excretions by individual animals were measured during the last $5 \mathrm{~d}$ of experimental period. During the last 3 days of each period, methane emissions were estimated for the group of 6 animals. To estimate methane, gas samples $(5 \mathrm{ml})$ of the tunnels exhaust stream were taken every hour and stored in vacutainers for later analysis (Molina et al., 2016). On the last day of each period, rumen contents were sampled from each animal (approximately $15 \mathrm{ml}$ ) using a rumen probe, discarding when possible saliva contamination was suspected. The sample of rumen content was filtered using two layers of cheese cloth. One aliquot was used to measure the $\mathrm{pH}$ with a potentiometer (Hanna $\mathrm{HI}$ 98140) and the other part of the rumen liquid was stored at $-20{ }^{\circ} \mathrm{C}$ for further analysis of the volatile fatty acids (VFA).

\section{Chemical Analysis}

Dry matter (DM, AOAC, 2005), crude protein (CP, method of Dumas; AOAC, 2005), ether extract (EE, $A O A C, 2005)$, neutral detergent fiber, acid detergent fiber, and acid detergent lignin (NDF, ADF, ADL, Van Soest et al., 1991), ash (AOAC, 2005) and gross energy (GE, calorimetric bomb Parr ${ }^{\circledR}$ 6510) were determined for forage and fecal samples. In addition, the concentration of condensed tannins in fodder was determined by the butanol-HCL method (Terrill et al., 1992). Nitrogen ammonia concentration in rumen fluid was determined by the colorimetric method, according to procedure described by Parra and A vila (2010).

Methane (from tunnel gas sample) and ruminal VFAs were quantified using a gas chromatograph (Shimadzu GC-2014) equipped with a flame ionization (FID) detector as described by Parra and Avila (2010) and Betancour (2001), respectively. 


\section{Statistical analysis}

An experimental model of switching was used with two treatments (grass only and grass:legume mixture diets) applied in sequence through three evaluation periods, where each experimental day was independent and considered as repetitions in the treatments. The model was descripted as:

$$
Y_{i j k}=\mu_{i k}+\varepsilon_{i j}+\theta_{i j k}
$$

\section{Forage chemical composition}

In this experiment, addition of legume hay to a diet base on hay grass increased the content of CP, ADL, and non-structural carbohydrates by $42.4,100$, and $34.5 \%$, respectively, but decrease the concentration of
Where, $Y_{i j k}$ was the response of the lamb; $\mu$ ik was the effect of the treatment in each sequence; $\varepsilon_{i j}$ was the random effect of each lamb in each sequence; and $\theta_{i \mathrm{ijk}}$ was the residual. For the analysis of variance, the SAS ${ }^{\circledR}$ GLM procedure was used as described by Martínez et al. (2011). Variables associated with intake, excretion the feces and digestibility considered the animal as experimental unit, while variables associated with methane production considered the group (6 lambs) as experimental unit.

\section{Results}

structural carbohydrates by $12.5 \%$. In fact, Kikuyu had a higher total carbohydrate content than the grass:legume mix diet in $15.2 \%$. However, the mixture of both forages contained $1.3 \%$ of condensed tannins, while kikuyu did not present condensed tannins (Table 1).

Table 1. Chemical composition (mean \pm standard deviation) of the kikuyu and kikuyu:lotus diets

\begin{tabular}{lrc}
\hline Composition & Kikuyu & Kikuyu:Lotus \\
\hline Crude protein, \% & $11.8 \pm 0.89$ & $16.8 \pm 0.48$ \\
Ether extract, \% & $1.3 \pm 0.09$ & $1.2 \pm 0.02$ \\
Neutral detergent fiber, \% & $69.9 \pm 0.20$ & $61.2 \pm 0.23$ \\
Acid detergent fiber, \% & $31.6 \pm 0.91$ & $31.3 \pm 0.88$ \\
Hemicellulose, \% & $38.4 \pm 0.96$ & $29.9 \pm 0.98$ \\
Cellulose, \% & $27.8 \pm 0.81$ & $23.7 \pm 0.36$ \\
Acid detergent lignin, \% & $3.8 \pm 0.54$ & $7.6 \pm 0.95$ \\
Ash, \% & $12.1 \pm 0.45$ & $12.9 \pm 0.63$ \\
Condensed tannins, \% & $0.0 \pm 0.0$ & $1.3 \pm 0.01$ \\
Non-structural carbohydrates ${ }^{1} \%$ & $4.9 \pm 1.10$ & $6.6 \pm 0.89$ \\
Total carbohydrates ${ }^{2} \%$ & $71.0 \pm 2.10$ & $60.2 \pm 1.80$ \\
Organic matter, \% & $87.9 \pm 0.45$ & $87.1 \pm 0.63$ \\
Gross energy (Kcal g $^{-1}$ ) & $3.9 \pm 0.01$ & $3.9 \pm 0.01$ \\
\hline
\end{tabular}

${ }^{1} \mathrm{NSC}: 100-(\mathrm{CP}+\mathrm{NDF}+\mathrm{Ash}+\mathrm{EE}+$ Condensed tannins)

${ }^{2} \mathrm{NDF}+\mathrm{NSC}-\mathrm{ADL}$

Intake, excretion of feces and digestibility of nutrients

Intake of DM, OM, ADL, and ADF was higher for the kikuyu:lotus mixture than for kikuyu-only diet $(p<$ 0.05) but NDF consumption did not differ between treatments. DM, OM, ADL, NDF, and ADF excretion in the feces was greater in animals that received the forage mixture diet ( $p<0.05$; Table 2). Likewise, apparent digestibility of DM and OM was higher in animals that receiving the mixture fodder $(p<0.05)$. However, apparent digestibility of NDF and ADF was higher in animals that ate only kikuyu hay $(p<0.05$; Table 3).

\section{A mmonia, pH, VFA's and methane production}

A mmoniacal nitrogen content in the rumen fluid was higher $(p<0.05)$ in animals fed kikuyu:lotus than in those fed on kikuyu alone ( 7.95 vs 5.44 vs. mmol $\mathrm{L}^{-1}$, Table 3). Rumen $\mathrm{pH}$ and total VFAs concentration did not differ between treatments. However, acetate concentration was lower $(p<0.01)$ and propionate ( $p$ $<0.1)$ and butyrate $(p<0.01)$ were greater in animals fed mixed kikuyu:lotus hay than in those fed kikuyu hay alone. The acetate:propionate ratio was higher ( $p$ $<0.05$ ) in animals that consumed pure grass (5.1 vs. 4.6) than in the forage mixture diet (Table 3).

Total methane emissions declined in lambs that consumed kikuyu:lotus, regardless of how it was expressed (gross, per unit of feed intake or digested matter; Table 4). The animal group that received kikuyu produced less methane if in the previous period they were fed kikuyu:lotus, suggesting a residual effect of the diet on methane production (Figure 1). 
Table 2. Dry matter intake, feces and urine production from lambs feeding kikuyu hay or kikuyu:lotus hay.

\begin{tabular}{|c|c|c|c|c|}
\hline Variable & Kikuyu & Kikuyu:Lotus & SEM $^{1}$ & $P$ \\
\hline \multicolumn{5}{|l|}{ Intake, g } \\
\hline Dry matter & 475.8 & 589.3 & 17.4 & *⿻丷木 \\
\hline N eutral detergent fiber & 332.9 & 360.9 & 9.7 & ns \\
\hline Acid detergent fiber & 150.3 & 184.6 & 5.4 & * \\
\hline Acid detergent lignin & 18.2 & 45.0 & 2.5 & *⿻1k \\
\hline Organic matter & 418.4 & 513.6 & 15.1 & 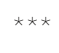 \\
\hline \multicolumn{5}{|l|}{ Feces, $\mathrm{g}$} \\
\hline Dry matter & 211.3 & 242.8 & 8.9 & * \\
\hline N eutral detergent fiber & 128.9 & 149.7 & 5.6 & * \\
\hline Acid detergent fiber & 70.7 & 94.9 & 3.8 & 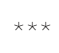 \\
\hline Acid detergent lignin & 26.8 & 46.0 & 2.2 & **1* \\
\hline Organic matter & 174.6 & 206.6 & 7.7 & *⿻丷木 \\
\hline \multicolumn{5}{|l|}{ Urine, ml } \\
\hline Total & 758.8 & 1211.3 & 73.7 & **1* \\
\hline
\end{tabular}

1SEM : Standard error of the mean. $* p<0.05$. ${ }^{* * *} p<0.01$. ns: non-significant.

Table 3. A pparent digestibility, rumen pH and fermentation products of lambs fed kikuyu hay or kikuyu:lotus hay.

\begin{tabular}{|c|c|c|c|c|}
\hline Variable & Kikuyu & Kikuyu:Iotus & SEM 1 & $P$ \\
\hline \multicolumn{5}{|l|}{ Apparent digestibility, \% } \\
\hline Dry matter & 56.0 & 58.9 & 0.9 & 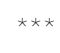 \\
\hline Neutral detergent fiber & 61.5 & 58.7 & 0.8 & * \\
\hline Acid detergent fiber & 53.4 & 48.8 & 1.1 & * \\
\hline Organic matter & 58.7 & 59.9 & 0.8 & + \\
\hline $\mathrm{pH}$ & 7.4 & 7.6 & 0.04 & ns \\
\hline Ammonia, mmol L-1 & 5.4 & 7.9 & 0.06 & * \\
\hline \multicolumn{5}{|l|}{ Volatile fatty acids } \\
\hline Total, mmol L-1 & 42.9 & 37.2 & 1.8 & ns \\
\hline A cetate, $\mathrm{mmol} 100 \mathrm{~mol}^{-1}$ & 79.4 & 76.0 & 0.4 & * $1 *$ \\
\hline Propionate, $\mathrm{mmol} 100 \mathrm{~mol}^{-1}$ & 15.7 & 16.7 & 0.2 & + \\
\hline Butyrate, $\mathrm{mmol} 100 \mathrm{~mol}^{-1}$ & 4.0 & 6.0 & 0.3 & 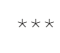 \\
\hline A cetate:propionate ratio & 5.1 & 4.6 & 0.08 & * \\
\hline
\end{tabular}

1SEM : Standard error of the mean. $+p<0.1 * p<0.05$. *** $p<0.01$. ns: non-significant.

Table 4. Methane emissions from lambs feeding kikuyu hay or kikuyu:lotus hay.

\begin{tabular}{|c|c|c|c|c|}
\hline Variable $^{1}$ & Kikuyu & Kikuyu:Lotus & SEM $^{1}$ & $P$ \\
\hline $\mathrm{g}$ animal $^{-1}$ & 27.6 & 23.1 & 0.03 & *AK \\
\hline $\mathrm{g} \mathrm{kg}^{-1} \mathrm{DM}$ intake & 18.8 & 12.2 & 0.41 & *** \\
\hline $\mathrm{g} \mathrm{kg}^{-1} \mathrm{FDN}$ intake & 26.9 & 19.9 & 0.51 & *** \\
\hline $\mathrm{g} \mathrm{kg}^{-1} \mathrm{OM}$ intake & 21.4 & 14.0 & 0.42 & * * * \\
\hline $\mathrm{g} \mathrm{kg}^{-1} \mathrm{DM}$ digested & 33.2 & 20.7 & 0.74 & *⿻一从火 \\
\hline $\mathrm{g} \mathrm{kg}^{-1}$ FDN digested & 43.5 & 33.9 & 0.84 & **1* \\
\hline $\mathrm{g} \mathrm{kg}^{-1} \mathrm{OM}$ digested & 36.1 & 23.4 & 0.76 & $* * *$ \\
\hline
\end{tabular}




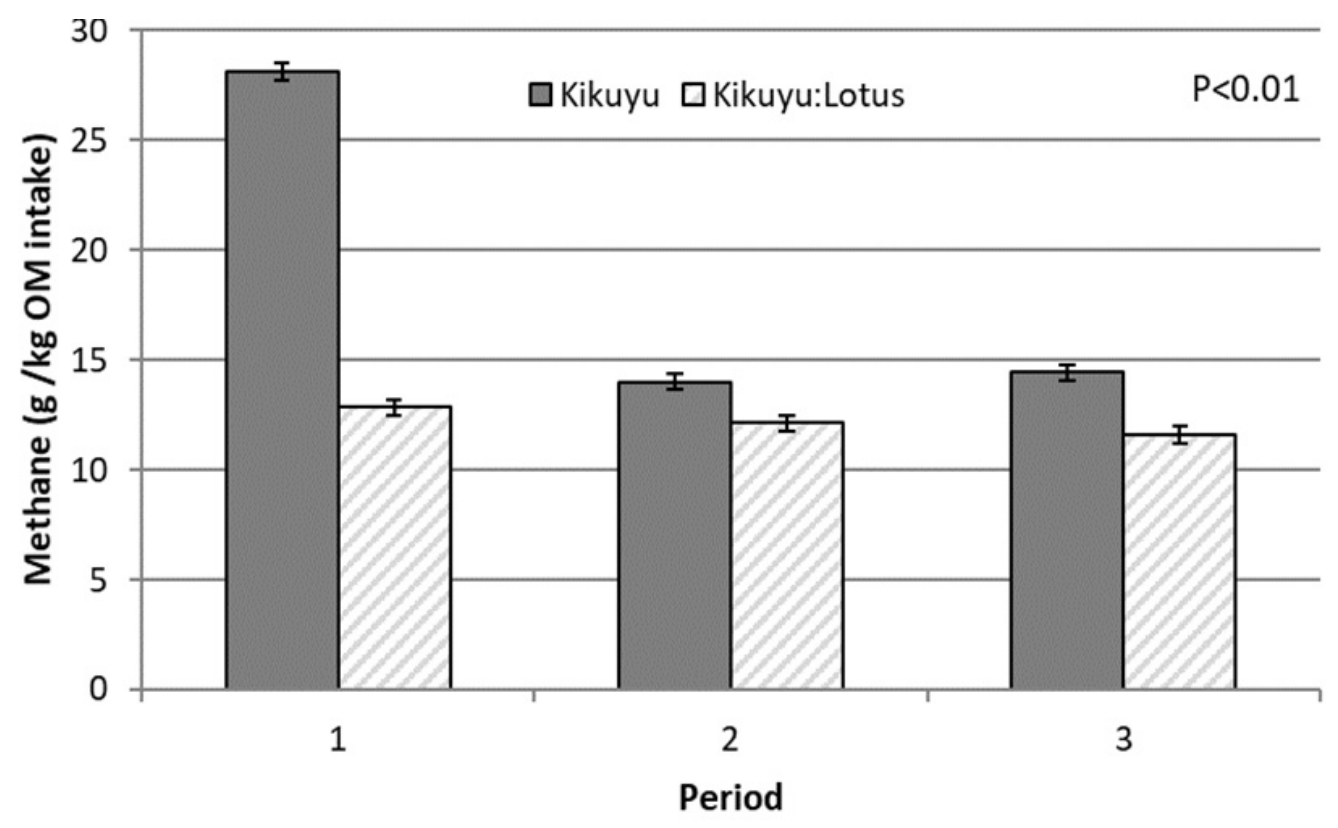

Figure 1. Methane emission ( $\mathrm{g} \mathrm{kg}^{-1} \mathrm{OM}$ consumed) from lambs fed kikuyu hay or kikuyu:lotus hay during the experimental period.

\section{Discussion}

Kikuyu is the main grass species used in cattle production systems in Colombian highlands (Carulla and Ortega, 2016). Recently, the legume Lotus uliginosus has been introduced to this region with excellent results in animal production (Castro et al., 2008; Morales et al., 2013). Some studies suggest that the use of legumes, and particularly tanniferous legumes, could reduce methane production by grazing ruminants (Molina et al., 2016; Waghorn, 2008). In our work, $30 \%$ inclusion of lotus hay decreased methane emission, both total daily emissions per animal and methane emissions by feed and nutrient intake, or feed and nutrient degrade.

Methane emission by ruminants fed legumes has presented contradictory responses. Clover hay inclusion to a basal diet of ryegrass hay increased methane emissions per unit of dry matter consumed by sheep (Carulla et al., 2005). However, other work has found that an increase in the proportion of clover in the ryegrass basal diet decreases methane emission per unit of dry matter consumed in cattle (Lee et al., 2004). Both experiments expose differences that may explain the contradictory results between these works. For example, in the first experiment, feed supply was restricted to $75 \mathrm{~g} \mathrm{~kg}^{-1}$ metabolic weight, while in the second experiment the intake was not restricted.

Some studies show that a greater forage allowance and legume inclusion to grass-based diet increases dry matter intake (Ribehiro-Filho et al., 2005; McCaugey et al., 1999) and when dry matter consumption increases there is a reduction in methane emissions per unit of dry matter intake due to a reduction in forage digestibility (Blaxter and Clapperton, 1965) and increase in passage rate (Pinares-Patiño et al., 2007). In our work, diets were offered, and voluntary intake of animals during the first part of each experimental period was determined. Later, offer was restricted to $90 \%$ of voluntary intake. Despite this restriction, dry matter intake increased because of legume addition.

Higher consumption in diets with legumes has been linked to increasing passage rate, due to decrease in structural carbohydrates concentration (Pinares-Patiño et al., 2007). Pinares-Patiño et al. (2003) reported an inverse relationship between passage rate and enteric methane production. The increase in passage rate decreases feed permanence time in rumen, which limits nutrients degradation and $\mathrm{H}_{2}$ and $\mathrm{CO}_{2}$ production. However, in our work, the apparent digestibility of DM and OM was higher in the diet of kikuyu and lotus diet but the degradability NDF was lower. A higher DM intake and digestibility would imply higher methane emissions, such as that observed in this work, unless it would be mainly related with NDF degradation (Tiemann et al., 2008b). Digestibility of NDF promote more acetate production, resulting in greater $\mathrm{H}_{2}$ and $\mathrm{CH}_{4}$ synthesis as will be discussed later.

Other possible explanation for lower methane emissions in diet with legumes could be related to changes in fermentation patterns. In our work, 
although VFA production did not presented significant differences among treatments, we observed $15.3 \%$ higher VFA concentration in lambs that received pure grass. Similar response was observed in vitro, when increased lotus proportion in grass:legume mixture decreased VFA production, that was attributed to a higher protein and condensed tannins concentration in the mixture (Vargas et al., 2014). In addition, we observed that including lotus hay reduced acetate concentration and decreased acetate:propionate ratio in rumen fluid. Methane formation as well as propionate synthesis require $\mathrm{H}_{2}$, while during acetate synthesis $\mathrm{H}_{2}$ is released. For this reason, a decrease in the acetate:propionate ratio or in the acetate concentration has been associated with a reduction in methane (M oss et al., 2000). A decrease in the acetate:propionate ratio has been reported in in vitro studies because of adding legumes to a diet with only grass (Stürm et al., 2007). However, neither in vitro (Hess et al., 2003) nor in vivo (Carulla et al., 2005) reported differences in acetate:propionate ratio.

Fermentation patterns are related to diet composition (Lovett et al., 2004). Diets rich in structural carbohydrates results in higher acetate proportion (Annison and Armstrong 1970). In our study, kikuyu diet had greater structural carbohydrate proportion, but NDF intake was similar between treatments. Also, the structural carbohydrates in kikuyu were more digestible than the mixed diet (Table 2). Murphy et al. (1982) reported that fermentation products of the same carbohydrates in rumen may be different when amending microbial populations according to diet characteristics and ruminal environment. In our experiment, ruminal environment characteristics were not very different, except by higher ammonia concentrations in the rumen fluid of those animals that included lotus hay due to higher concentration and protein degradation. However, it is also probably that carbohydrate concentration could modify VFA fermentation pattern. Other factors such as the presence of tannins in lotus could help to explain these changes, as some studies have reported changes in VFA profile due to tannins inclusion (Bhatta et al., 2009).

L. uliginosus is a legume with moderate condensed tannins content and in this study the mixture contained low concentrations of condensed tannins. Tanniferous legumes inclusion in ruminant diet has been linked to methane emissions reduction (Waghorn 2008; Woodward et al., 2004). In studies with animals feeding tanniferous plants like Lotus corniculatus or $\mathrm{H}$ edysarum coronarium reductions between 18 and $23 \%$ in methane emissions per unit of dry matter intake in sheep and cattle (Woodward et al., 2001; 2004). In the present experiment, inclusion of $30 \%$ lotus hay decreased methane emission per unit of dry matter intake by $35 \%$. Waghorn (2008) suggests that condensed tannins presence limits degradation affecting nutrient availability, ruminal enzyme activity or ruminal microorganisms and could decrease methane production. We observed lower lotus digestibility respect to other species evaluated in in vitro assays (Vargas et al., 2018b), as well as lower digestibility of fodder mixture when lotus inclusion was increased (Vargas et al., 2014). However, in the present experiment, the digestibility of DM and OM was higher in the animals that received the kikuyu:lotus mixture, so the lower digestibility as a consequence of the addition of tannins cannot be the explanation for the lower methane production observed.

Tavendale et al. (2005) suggest that condensed tannins in lotus could affect specific methanogenic populations, while others authors found that in vitro lotus incubation decreased methane production (Vargas et al., 2018b). The inhibitory effect of condensed tannins on methanogenic populations may be an alternative route of $\mathrm{H}_{2}$ utilization, such as propionate synthesis, nitrate reduction, and lipid biohydrogenation (Janssen, 2010; Moss et al., 2000). The concentration of $\mathrm{H}_{2}$ increases in the gas exhaled by ruminants soon after they are fed fodder and concentrate diets (Pinares-Patiño et al., 2011, Lopes et al., 2016). It has also been suggested that the presence of condensed tannins could affect cellulolytic bacteria (Patra and Saxena, 2010) by reducing fiber degradation, then decreasing acetate production and consequently methane emission. In this study, the degradation of the fiber fraction and the proportion of acetate decreased, and the proportion of propionate showed a tendency to increase because of the addition the lotus, which could partially explain the lower methane emissions.

In our work we found a residual effect due to the inclusion of the lotus for the most of the variables evaluated despite having made an adjustment period of 15 days between the experimental periods. For example, although methane production per unit of dry matter intake was lower in animals receiving $30 \%$ lotus hay the in diet, animals fed with kikuyu diet showed a residual effect on methane production after receiving lotus hay (Figure 1 ). This result indicates that methane production is lower in animals that have previously consumed the mixed diet based on grass and tannin legumes. The decrease in methane production is possibly due to the inhibitory effect of 
tannins in some microbial populations in the rumen, which occurred at least during 15-day experiment. Secondary compounds can modify microbial populations in the rumen, but the effect may be transient because the microbial population in the rumen may adapt to a new condition and reestablish the overall initial state, either modifying or no the initial microbial community (Newbold and Ramos, 2020). However, the residual effect of secondary compounds on methane emissions has not been reported in the literature.

Conflict of interest. The authors declare they have no conflicts of interest regarding to the work presented in this report.

\section{Acknowledgment}

The authors are grateful to the Ministry of Agriculture and Rural Development (MARD) of the Republic of Colombia for the financing of this work. Additionally, to Mauricio Avila for the field and laboratory collaboration in this experiment.

\section{Literature Cited}

Annison, E. F. and D.G. Armstrong. 1970. Physiology of digestion and metabolism in the ruminant. Ed: Oriel Press, Ltd. Newcastle, England.

Archimède, H., M. Eugène, C. Magdeleine, M. Boval, C. Martin, D. Morgavi, P. Lecomte and M. Doreau. 2011. Comparison of methane production between C3 y C4 grasses and legumes. Anim. Feed Sci. Tech. 166-167:

59-64.

https:/ / doi.org/ 10.1016/ j.anifeedsci.2011.04.003

AOAC. 2005. Official methods of analysis. 18th ed. Ed. Association of Official Agricultural Chemists. Washington D.C. USA.

Bhatta, R., Y. Uyeno, A. Takenaka, Y. Yabumoto, I. Nonaka, O. Enishi and M. Kurihara. 2009. Difference in the nature of tannins on in vitro ruminal methane and volatile fatty acid production and on methanogenic archaea and protozoal population. J. Dairy Sci. 92: 5512-5522. https:/ / doi.org/ 10.3168/ jds.2008-1441

Betancourt, M., M. Martínez de Acurero, T. Clavero, R. Razz, S. Pietrosemoli y O. A raujo-Febres. 2003. Efecto de la melaza, ácido fórmico y tiempo de fermentación sobre el pH y temperatura en microsilos de Leucaena leucocephala. Rev. Fac. Agron. (LUZ). 20: 493-501. https:/ / produccioncientificaluz.org/ index.php/ agr onomia/ article/ view/ 26475/ 27101

Blaxter K., and J. Clapperton. 1965. Prediction of the amount of methane produced by ruminants. Brit. J. Nutr. 19:

511-522. https:/ / doi.org/ 10.1079/ BJN 19650046

Carulla, J., M. Kreuzer, A. Machmüller and H. Hess. 2005. Supplementation of A cacia mearnsii tannin decreases methanogenesis and urinary nitrogen in forage-fed sheep. Aust. J. Agr. Res. 56: 961-970. https:/ / doi.org/ 10.1071/ AR05022
Carulla, J., and E. Ortega. 2016. Sistemas de producción lechera en Colombia: Retos y oportunidades. Arch. Latinoam. Prod. Anim. 24: 83-87. https:/ / ojs.alpa.uy/ index.php/ ojs_files/ article/ vie w/ 2526

Castro, E., J. Mojica, J. León, M. Pabón, J. Carulla and E. Cárdenas. 2008. Productividad de pasturas y producción de leche bovina bajo pastoreo de gramínea y gramínea + Lotus uliginosus en Mosquera, Colombia. Rev. Med. Vet. Zoot. 55: 9-21. https:/ / doi.org/ 10.15446/ rfmvz

Gerber, P., H. Steinfeld, B. Henderson, A. Mottet, C. Opio, J. Dijkman, A. Falcucci and G. Tempio. 2013, Tackling climate change through livestock - A global assessment of emissions and mitigation opportunities. Food and Agriculture Organization of the United Nations (FAO). Roma, Italia.

Hess, H., L. Monsalve, C. Lascano, J. Carulla, T. Díaz and M Kreuzer. 2003. Supplementation of a tropical grass diet with forage legumes and Sapindus saponaria fruits: effects on in vitro ruminal nitrogen turnover and methanogenesis. Aust. J. Agr. Res. 54: 703-713. https:/ / doi.org/ 10.1071/ A R02241

Janssen, P. 2010. Influence of hydrogen on rumen methane formation and fermentation balances through microbial growth kinetics and fermentation thermodynamics. Anim. Feed Sci. Tech. 160: 1-22. https:/ / doi.org/ 10.1016/ j.anifeedsci.2010.07.002

Johnson, K., and D.E. Johnson. 1995. Methane emissions from cattle. J. Anim. Sci. 73: 2483-2492. https:/ / doi.org/ 10.2527/ 1995.7382483x

Lee, J., S. Woodward, G. Waghorn and D. Clark. 2004. Methane emissions by dairy cows fed increasing proportions of white clover (Trifolium repens) in pasture. Pr. N. Z. Grassl. Assoc. 66: 151-155. https:/ / www.grassland.org.nz/ publications/ nzgra ssland_publication_430.pdf 
Lopes, J., L. de Matos, M. Harper, F. Giallongo, J. Oh, D. Gruen, S. Ono, M. Kindermann, S. Duval and A. Hristov. 2016. Effect of 3-nitrooxypropanol on methane and hydrogen emissions, methane isotopic signature, and ruminal fermentation in dairy cows.
J. Dairy
Sci.
99:
5335-5344.

https:/ / doi.org/ 10.3168/ jds.2015-10832

Lovett, D., D. McGilloway, A. Bortolozzo, M. Hawkins, J. Callan, B. Flynn and F. O'Mara. 2005. In vitro fermentation patterns and methane production as influenced by cultivar and season of harvest of Lolium perenne L. Grass Forage Sci. 61: 9-21. https:/ / doi.org/ 10.1111/ j.1365-2494.2006.00500.x

Lovett, D., A. Bortolozzo, P. Conaghan, P. O'Kiely and F. O'Mara. 2004. In vitro total and methane gas production as influenced by rate of nitrogen application, season of harvest and perennial ryegrass cultivar. Grass Forage Sci. 59: 227-232. https:/ / doi.org/ 10.1111/ j.1365-2494.2004.00421.x

Martínez, R., N. Martínez and M. Martínez. 2011. Diseño de experimentos en ciencias agropecuarias y biológicas con SAS, SPSS, R y Statistix. 1st Edition. Ed: Fondo Nacional Universitario. Bogotá, Colombia

Makkar, H. 2016. Smart livestock feeding strategies for Makkar, H. 2016. Smart livestock feeding strategies for harvesting triple gain - the desired outcomes in planet, people and profit dimensions: a developing country perspective. Anim. Prod. Sci. 56: 519-534. https:/ / doi.org/ 10.1071/ AN 15557

McCaughey, W., K. Wittenberg and D. Corrigan. 1999. Impact of pasture on methane production by lactating beef cows. Can. J. Anim. Sci. 79: 221-226. https:/ / doi.org/ 10.4141/ A98-107

Molina, I., E. Angarita, O. Mayorga, J. Chará and R. Barahona. 2016, Effect of Leucaena leucocephala on methane production of Lucerna heifers fed a diet base don Cynodon plectostachyus. Livest. Sci. 185: 24 29. https:/ / doi.org/ 10.1016/ j.livsci.2016.01.009

Morales, A., J. León, E. Cárdenas, G. Afanador and J. Carulla. 2013, Composición química de la leche, digestibilidad in vitro de la materia seca y producción en vacas alimentadas con gramíneas solas o asociadas con Lotus uliginosus. Rev. Med. Vet. Zoot. 60: 32-48. https:/ / doi.org/ 10.15446/ rfmvz

Moss, A., J. Jouany and J. Newbold. 2000. Methane production by ruminants: its contribution to global warming. Ann. Zoot. 49: 231-253. https:/ / doi.org/ ff10.1051/ animres:2000119

Murphy, M., R. Baldwin and L. Koong. 1982. Murphy, M., R. Baldwin and L. Koong. 1982. Estimation of stoichiometric parameters for rumen fermentation of roughage and concentrate diets. J Anim. Sci. 55: 411-421. https:/ / doi.org/ 10.2527/ jas1982.552411x

Newbold, C., E Ramos. 2020. Ruminal microbiome and microbial metabolome: effects of diet and ruminant host. Animal. 14:78-86. https:/ / doi.org/ 10.1017/ S1751731119003252

Parra, D., and M. A vila. 2010. Determinación de los parámetros fisiológicos y dinámica ruminal de bovinos en condiciones de poli-túnel para evaluar emisiones de metano en trópico alto y bajo colombiano. Facultad de Ciencias Agropecuarias. Universidad de Cundinamarca. Fusagasugá, Colombia.

Patra, A., and J. Saxena. 2010. Review: A new perspective on the use of plant secondary metabolites to inhibit methanogenesis in the rumen. Phytochemistry. $\quad 71$ : 1198-1222. https:/ / doi.org/ 10.1016/ j.phytochem.2010.05.010

Pinares-Patiño, C., J. McEwan, K. Dodds, E. Cardenas, R. Hegarty, J. Koolaard and H. Clark. 2011. Repeatability of methane emissions from sheep. Anim. Feed Sci. Tech. 166: 210-218. https:/ / doi.org/ 10.1016/ j.anifeedsci.2011.04.068

Pinares-Patiño, C., G. Waghorn, A. Machmüller, B. Vlaming, G. Molano, A. Cavanagh and H. Clark. 2007. Methane emissions and digestive physiology of non-lactating dairy cows fed pasture forages. Can J. Anim. Sci. 87: 601-613. https:/ / doi.org/ 10.4141/ CJAS06023

Pinares-Patiño, C., M. Ulyatt, K. Lassey, T. Barry and C. Holmes. 2003. Rumen function and digestion parameters associated with differences between sheep in methane emissions when fed chaffed Lucerne hay. J. Agr. Sci. 140: 205-214. https:/ / doi.org/ 10.1017/ S0021859603003046

Ribeiro-Filho, H., R. Delagarde and J. Peyraud. 2005. Herbage intake and milk yield of dairy cows grazing perennial ryegrass swards or white clover/ perennial ryegrass swards at low and medium herbage allowance. Anim. Feed Sci. Tech. 119:

https:/ / doi.org/ 10.1016/ j.anifeedsci.2004.12.009

Stürm, C., T. Tiemann, C. Lascano, M. Kreuzer and H. Hess. 2007. Nutrient composition and in vitro ruminal fermentation of tropical legume mixtures with contrasting tannin contents. Anim. Feed Sci. Tech. $\quad$ 138: 29-46. https:/ / doi.org/ 10.1016/ j.anifeedsci.2006.11.008

Tavendale, M., L. Meagher, D. Pacheco, N. Walker, G. Attwood and S. Sivakumaran. 2005. Methane production from in vitro rumen incubations with 
Lotus pedunculatus and M edicago sativa, and effects of extractable condensed tannin fractions on methanogenesis. Anim. Feed Sci. Tech. 123-124: 403419.

https:/ / doi.org/ 10.1016/ j.anifeedsci.2005.04.037

Terrill, T., A. Rowan, G. Douglas and T. Barry. 1992. Determination of extractable and bound condensed tannin concentration in forage plants, protein concentrated meals and cereal grains. J. Sci. Food Agr. 58: 321-329. https:/ / doi.org/ 10.1002/ jsfa.2740580306

Tiemann, T., C. Lascano, H. Wettstein, A. Mayer, M. Kreuzer and H. Hess. 2008a. Effect of the tropical tannin-rich shrub legumes Calliandra cal othyrsus and Flemingia macrophylla on methane emission and nitrogen and energy balance in growing labs. Animal. 2: 790-799. https:/ / doi.org/ 10.1017/ S1751731108001791

Tiemann, T., C. Lascano, M. Kreuzer and H. Hess. 2008b. The ruminal degradability of fiber explains part of the low nutritional value and reduced methanogenesis in highly tanniferous tropical legumes. J. Sci. Food Agr. 88:1794-1803. https:/ / doi.org/ 10.1002/ jsfa.3282

Van Soest, P., J. Robertson and B. Lewis. 1991. Methods for dietary fiber, neutral fiber and no starch polysaccharides in relation to nutrition. J. Dairy Sci. 74: 3583-3597. https:// doi.org/ 10.3168/ jds.S00220302(91)78551-2

Vargas, J., A. Sierra, J. Benavidez, Y. A vellaneda, O. Mayorga and C. Ariza. 2018a. Establecimiento y producción de raigrás y trébol en dos regiones del trópico alto colombiano. Agron. Mesoam. 29:177191. https:/ / doi.org/ 10.15517/ ma.v29i1.28077
Vargas, J., M. Pabón and J. Carulla. 2018b. Methane production from four forages at three maturity stages in a ruminal in vitro system. Rev. Colomb. Cienc. Pecu. 31: 120-129. https:/ / doi.org/ 10.17533/ udea.rccp.v31n2a05

Vargas, J., M. Pabón and J. Carulla. 2014. Producción de metano in vitro en mezcla de gramíneasleguminosas del trópico alto colombiano. Arch. Zootec.

63:

397-407.

http:/ / dx.doi.org/ 10.4321/ S000405922014000300001

Waghorn, G. 2008. Beneficial and detrimental effects of dietary condensed tannins for sustainable sheep and goat production - Progress and challenges. Anim. Feed Sci. Tech. 147: 116-139. https:/ / doi.org/ 10.1016/ j.anifeedsci.2007.09.013

Waghorn, G., H. Clark, V. Taufa and A. Cavanagh. 2007. Monensin controlled release capsules for improved production and mitigating methane in dairy cows fed pasture. Proc. New. Zeal. Soc. An. 67: 266-271. http:/ / www.sciquest.org.nz/ node/ 147512

Woodward, S., G. Waghorn and P. Laboyrie. 2004. Condensed tannins in birdsfoot trefoil (Lotus corniculatus) reduce methane emissions from dairy cows. Proc. New. Zeal. Soc. An. 64: 160-164.

Woodward, S., G. Waghorn, M. Ulyatt and K. Lassey. 2001. Early indications that feeding Lotus will reduce methane emissions from ruminants. Proc. New. Zeal. Soc. An. 61: 23-26. 